\title{
Hubungan Usia Mengalami Menarche dengan Kepercayaan Diri pada Siswi SMA
}

\author{
Frihapma Semita Ade \\ Universitas Putra Indonesia "YPTK Padang, Indonesia \\ E-mail: frihapma.semita@gmail.com
}

\begin{abstract}
This study aims to determine whether there is a relationship between age experiencing of menarche (first menstruation) with the student's confidence in a high school in Padang. The population of the study was all students at Senior High School 6 Padang. The sampling technique used was proportionate stratified random sampling. The number of samples used was 186 people using a questionnaire that had been tested for its validity and reliability before. The results of this study indicate that the age of menarche has a significant relationship to the confidence of these students. Besides that, the correlation coefficient is negative hence the faster a person experiences menarche, the lower confidence she will has. The relationship between age of experiencing menarche with self-confidence is significant because the physical and psychological changes that occur after a person experiences menarche can affect one's confidence. Even so, it is not only the age of menarche that is associated with self-confidence, but there are other factors such as the learning process of the environment, family, friends or the community. It is because self-confidence is not a hereditary factor, so that everyone can increase their self-confidence in order to optimize their potential for success.
\end{abstract}

Keywords: menarche, confidence, school

\begin{abstract}
Abstrak
Penelitian ini bertujuan untuk mengetahui apakah terdapat hubungan antara usia mengalami menarche (haid pertama kali) dengan kepercayaan diri pada siswi sekolah menengah atas di Padang. Populasi penelitian ini adalah semua siswi di SMAN 6 Padang. Teknik pengambilan sampel yang digunakan adalah proportionate stratified random sampling. Jumlah sampel yang digunakan adalah 186 orang dengan menggunakan kuesioner yang telah diuji validitas dan reliabilitas sebelumnya. Hasil dari penelitian ini menunjukkan bahwa usia mengalami menarche memiliki hubungan yang signifikan terhadap kepercayaan diri para siswi tersebut. Selain itu hasil koefisien korelasi bernilai negatif, sehingga semakin cepat seseorang mengalami menarche maka kepercayaan dirinya akan semakin rendah. Hubungan antara usia mengalami menarche dengan kepercayaan diri ini bernilai signifikan karena perubahan fisik dan psikis yang terjadi setelah seseorang mengalami menarche bisa mempengaruhi kepercayaan diri seseorang. Meskipun begitu bukan hanya usia mengalami menarche saja yang berhubungan dengan kepercayaan diri, tetapi ada faktor-faktor lain seperti proses belajar dari lingkungan baik keluarga, teman ataupun masyarakat. Oleh karena kepercayaan diri bukan merupakan faktor keturunan, maka setiap orang bisa meningkatkan kepercayaan dirinya supaya bisa mengoptimalkan potensi yang dimiliki untuk meraih kesuksesan.
\end{abstract}

Kata kunci: menarche, kepercayaan diri, sekolah

\section{Pendahuluan}

Pertumbuhan dan perkembangan selalu dialami manusia sepanjang rentang kehidupannya. Perkembangan biasanya digambarkan dalam periode-periode tertentu. Klasifikasi masa perkembangan yang paling umum dipakai adalah sebagai berikut: masa sebelum kelahiran (prenatal), masa bayi, masa kanak-kanak awal, masa kanak-kanak tengah dan akhir, masa remaja, masa dewasa awal, tengah dan masa dewasa akhir (John W. Santrock, 2003). Diantara sekian banyak fase perkembangan, masa remaja merupakan fase dimana individu mencari identitas dirinya 
serta mengalami perubahan fisik dan psikis yang cepat. Masa remaja dimulai kira-kira usia 10 sampai 13 tahun dan berakhir antara usia 18 dan 22 tahun. Pada masa ini terjadi perubahan biologis, kognitif, dan sosial emosional. Sebelum memasuki masa remaja, seseorang akan mengalami masa pubertas yaitu perubahan cepat pada kematangan fisik yang meliputi perubahan tubuh dan hormonal yang terjadi pada masa remaja awal. Pubertas pada laki-laki ditandai dengan mimpi basah dan menarche (menstruasi pertama) pada perempuan. Menarche pada perempuan terjadi pada usia yang berbeda-beda. Secara khusus, perempuan mengalami menarche pada usia antara 12 dan 13 tahun, tetapi selalu terdapat perempuan yang mengalaminya pada usia lebih awal, kira-kira 10 tahun dan beberapa diantaranya bahkan lebih dini. Dilain pihak beberapa perempuan mungkin belum mengalami menstruasi sampai usia 15 tahun atau 16 tahun. Ini semua tergantung pada produksi dan pelepasan hormon (Robert P. Masland \& David Estridge, 2004). Dimulainya pubertas dan menarche seringkali dideskripsikan sebagai peristiwa utama dalam sejarah kehidupan remaja. Secara mendasar, pandangan ini mengisyaratkan perubahan pada masa puber dan kejadian seperti menarche menyebabkan perubahan fisik yang juga menuntut perubahan dalam konsep diri yang mungkin menyebabkan krisis identitas. Perubahan fisik yang terjadi setelah menarche diantaranya adalah buah dada mengembang, pinggul melebar, rambut tumbuh diketiak dan disekitar alat kelamin, bentuk tubuh menjadi sedikit bulat karena lemak mulai menumpuk, tinggi badan dan berat badan bertambah, wajah berubah bentuk dan menjadi berisi, kulit lebih berminyak, berkeringat lebih banyak dan mungkin muncul jerawat (Wendy Darvill \& Kelsey Power, 2003). Perubahan fisik ini menyebabkan terjadinya perubahan pada psikis atau emosional remaja yaitu mudah marah, malu dan tidak percaya diri. Remaja menjadi sangat memperhatikan tubuh mereka dan membangun citranya sendiri mengenai bagaimana tubuh mereka tampaknya. Perhatian yang berlebihan terhadap citra tubuh sendiri, amat kuat pada masa remaja dan bahkan ada yang menjadi tidak puas dengan keadaan tubuhnya. Semakin cepat seseorang mengalami menarche, maka fisiknya juga semakin berkembang dan berubah. Remaja akan selalu membandingkan bentuk fisiknya dengan fisik temantemannya serta membandingkan dengan bentuk fisik yang ideal dalam masyarakat. Bentuk fisik ideal dilihatnya melalui iklan di TV, sinetron, majalah dan sosial media yang mengidolakan tubuh yang tinggi, kulit putih, wajah bersih tidak berjerawat dan langsing. Jika tidak sesuai dengan konsep ideal masyarakat tersebut, maka banyak remaja menjadi tidak percaya diri dan akan mengembangkan pandangan negatif tentang dirinya dan berusaha dengan berbagai cara membeli dan menggunakan produk-produk yang ada di TV, majalah dan sosial media agar penampilannya lebih menarik. Data awal penelitian yaitu dengan melakukan interview pada beberapa siswi SMA N 6 Kota Padang menunjukkan bahwa beberapa siswi tersebut merasa kurang percaya diri kalau masa pubertasnya yang ditandai dengan menarche datangnya lebih lambat dibandingkan temantemannya. Begitu juga dengan yang mengalami menarche lebih cepat dibandingkan dengan temantemannya, mereka merasa apakah yang terjadi pada dirinya normal dan tidak memiliki masalah yang berarti karena perubahan fisik dan psikologis yang mereka rasakan terjadi pada saat dan setelah datangnya menarche tersebut. Sehubungan dengan latar belakang masalah diatas, maka peneliti tertarik untuk melakukan penelitian mengenai hubungan usia mengalami menarche dengan kepercayaan diri pada siswi di SMA Negeri 6 Kota Padang.

\section{Metode Penelitian}

Jenis penelitian ini adalah penelitian korelasional/ hubungan (correlation research). Penelitian korelasional ini adalah penelitian yang dilakukan untuk menggabungkan antara dua variabel atau lebih. Variabel independen penelitian ini adalah usia mengalami menarche dan variabel dependennya adalah kepercayaan diri. Penelitian dilakukan di SMA N 6 Padang. Populasi dalam penelitian ini adalah siswi SMA N 6 Padang yang berjumlah 360 orang. Teknik pengambilan sampel menggunakan proportionate stratified random sampling yaitu pengambilan sampel dari anggota populasi dengan acak dan berstrata secara proporsinal, sehingga jumlah sampel dalam penelitian ini yaitu 186 orang. Teknik pengumpulan data dalam penelitian ini menggunakan instrumen yang berupa skala psikologi dalam bentuk kuesioner. Kuesionernya ada dua yaitu kuesioner variabel independen yang berisi data usia responden dan usia mengalami menarche. 
Kuesioner variabel kedua yaitu skala kepercayaan diri yang telah dilakukan uji coba (try out) terlebih dahulu kepada 60 orang siswi SMA yang memiliki karakteristik yang sama dengan sampel penelitian. Setelah didapatkan hasil uji validitas dan reliabilitas alat ukur skala kepercayaan diri, maka kuesioner tersebut diberikan kepada sampel penelitian. Responden yang menjadi sampel penelitian diminta menandatangani informed consent dan mengisi kuesioner yang ada. Data yang sudah terkumpul diolah dengan menggunakan program SPSS (Statistical Product and Service Solution). Analisis data penelitian ini menggunakan analisis kuantitatif yang menggunakan model statistik. Teknik statistik untuk analisis koefisien korelasi dalam penelitian ini menggunakan nilai Koefisien Korelasi Jaspen's (M). Rumus koefisien korelasi Jaspen's (M) ini digunakan karena jenis variabel pertama dan variabel kedua penelitian yang bersifat ratio dan ordinal. Setelah mengetahui nilai koefisien korelasi Jaspen's maka dilakukan uji statistik dengan mengubahnya menjadi nilai Pearson (r) dan dilakukan uji z untuk mengetahui hubungan antara variable apakah signifikan atau tidak dengan taraf nyata $(\alpha)$ sebesar $1 \%$.

\section{Hasil Dan Pembahasan}

Berdasarkan penelitian yang telah dilakukan, data menunjukkan dari 186 sampel/ responden, terdapat 126 orang $(67,74 \%)$ yang mengalami menarche dalam kategori rata-rata (sedang), dan 4 orang $(2,15 \%)$ cepat dalam menarche dan terdapat 56 orang $(30,11 \%)$ yang tergolong lambat dalam mengalami menarche. Kemudian hasil kurva normal tentang tingkat kepercayaan diri menunjukkan $41 \%$ responden memiliki kepercayaan diri yang sangat tinggi, 55\% responden memiliki tingkat kepercayaan diri yang tinggi dan terdapat $4 \%$ yang memiliki tingkat kepercayaan diri dalam kategori rata-rata atau sedang. Hasil analisis pengolahan data kuesioner penelitian juga menunjukkan bahwa hipotesis penelitian diterima yaitu ada hubungan antara usia mengalami menarche dengan kepercayaan diri. Hal ini berdasarkan hasil uji $\mathrm{Z}$ dimana $\mathrm{H}_{\mathrm{o}}$ ditolak $\left(\mathrm{H}_{1}\right.$ diterima) apabila $\mathrm{Z}_{0}>\mathrm{Z}_{\alpha}$. Uji $Z$ dilakukan karena jumlah sampel penelitian cukup besar $(n>30)$. Nilai yang didapatkan yaitu $Z_{0}>Z_{\alpha}(2,571>0.004)$. Nilai koefisien korelasi yang didapatkan bertanda negatif. Ini berarti bahwa varibel-variabel penelitian berkorelasi negatif yang artinya semakin cepat usia seseorang mengalami menarche maka kepercayaan dirinya akan semakin rendah. Hasil penelitian ini juga menyatakan bahwa ada hubungan antara usia mengalami menarche dengan kepercayaan diri, namun nilai kontribusinya tidak terlalu besar karena kepercayaan diri juga berhubungan dengan faktor-faktor lain.Dari penelitian yang telah dilakukan terlihat bahwa ada hubungan yang signifikan antara usia mengalami menarche dengan kepercayaan diri. Hal ini sesuai dengan teori yang dikemukakan oleh Elizabeth Hurlock (1980) yang mengatakan bahwa perubahan sikap dan perilaku yang terjadi pada masa puber (setelah menarche) adalah ingin menyendiri, bosan, inkoordinasi, antagonisme sosial, emosi yang tinggi dan hilangnya kepercayaan diri. Imelda (2004) juga mengatakan bahwa perubahan atau efek haid pada remaja putri memiliki berbagai macam hubungan yaitu pada fisik, emosi yang berkaitan dengan kepercayaan diri, serta perilaku. Adanya hubungan antara menarche dengan kepercayaan diri ini juga sesuai dengan apa yang dikemukakan oleh John W. Santrock tentang dimensi psikologis pada masa pubertas yaitu setelah terjadinya menarche yang menandai dimasukinya masa puber, remaja putri lebih sering memperhatikan keadaan fisiknya dan sering tidak puas dengan perubahan keadaan fisiknya tersebut, sehingga persepsi dan citra diri yang terbentuk adalah negatif yang mengakibatkan mereka menjadi tidak percaya diri. Pada dasarnya kepercayaan diri seseorang itu perkembangannya dibentuk oleh banyak faktor. Menurut Rogers, sikap percaya diri tumbuh dalam diri seseorang karena proses memahami diri sendiri dan berkembangnya diawali dengan proses pengenalan diri secara fisik dan berkembang dengan berbagai pengalaman yang dialami seseorang. Hal ini juga sejalan dengan penelitian yang dilakukan oleh Primastuti (2010) bahwa seseorang yang memiliki pengetahuan yang tinggi tentang menarche, maka sikapnya akan lebih positif. Gambaran hasil penelitiannya menunjukkan bahwa mayoritas responden telah siap menghadapi menarche sehingga mempunyai sikap positif terhadap menarche. Sikap positif ditunjukkan dengan rasa keikhlasan ketika dia tahu bahwa sudah menuju dewasa, percaya diri, tidak takut dan tidak cemas terhadap apa yang dialaminya. Derry Iswidharmanjaya juga mengatakan 
bahwa percaya diri itu berkembang dari pola asuh/ proses belajar dari orangtua, konsep diri, dan efek interaksinya dengan orang lain. Berarti fenomena yang terjadi dilapangan saat melakukan penelitian ini juga sesuai dengan teori yang mengatakan bahwa ada hubungannya antara usia mengalami menarche dengan kepercayaan diri. Jumlah responden yang cepat dalam mengalami menarche di SMA N 6 Padang tidak banyak yaitu hanya 4 orang dan kepercayaan dirinya berada dalam taraf sedang (rata-rata). Dari hasil penelitian tersebut dapat dikatakan bahwa tidak hanya usia mengalami menarche saja yang memiliki kontribusi signifikan untuk mempengaruhi kepercayaan diri seseorang. Banyak faktor yang bisa menyebabkan seseorang bisa bertambah kepercayaan dirinya ataupun berkurang. Beberapa diantaranya adalah bagaimana hubungan remaja tersebut dengan orang tua, penerimaan teman sebaya dan perkembangan ilmu pengetahuan yang diterima oleh remaja tersebut. Hal ini juga dikuatkan dengan hasil penelitian yang dilakukan oleh Malika (2017) bahwa ada hubungan yang signifikan antara pengetahuan tentang menstruasi dengan kesiapan menghadapi menarche pada remaja putri di Malang. Penelitian lain yang berhubungan dengan ini dilakukan oleh Hidayatus Sholeha (2016) yang mengatakan bahwa ada hubungan antara kesiapan menghadapi menarche dengan tingkat kecemasan pada siswi di Kabupaten Jember. Variabel kesiapan mengadapi menarche menyumbang terhadap tingkat kecemasan sebesar 14\% dan $86 \%$ tingkat kecemasan dipengaruhi oleh faktor lain. Pengetahuan dan kesiapan psikologis yang kurang dalam menghadapi menarche akan berdampak pada penurunan prestasi belajar, penurunan kepercayaan diri, depresi dan isolasi sosial. Oleh sebab itu, dari berbagai hasil penelitian termasuk yang sudah peneliti lakukan di SMA N Padang, maka dapat dikatakan bahwa remaja putri sebaiknya memanfaatkan kemajuan perkembangan teknologi saat ini untuk menambah pengetahuan dalam berbagai hal terutama tentang menstruasi yang secara kodratnya pasti akan dialami oleh setiap perempuan baik secara cepat ataupun lambat. Mereka juga sebaiknya tidak hanya mengandalkan teknologi saja tetapi juga harus menambah pengetahuan dari lingkungan terdekat yang dipercaya seperti orangtua/keluarga. Remaja putri perlu membangun hubungan dan interaksi yang baik dengan berbagai pihak agar informasi yang didapatkan lebih tepat dan dapat diandalkan. Hubungan baik dengan orangtua, teman-teman dan masyarakat luas diperlukan agar remaja putri mendapatkan dukungan sosial emosional dalam menghadapi masa pubertas yang tidak mudah untuk dilalui bagi setiap orang. Dukungan ini sangat dibutuhkan oleh remaja putri karena perubahan fisik dan psikologis yang cukup cepat dialami oleh mereka.

\section{Kesimpulan}

Berdasarkan hasil penelitian tentang hubungan usia mengalami menarche dengan kepercayaan diri pada siswi di SMA N 6 Padang menunjukkan bahwa ada hubungan yang signifikan antara usia mengalami menarche dengan kepercayaan diri. Walaupun memiliki hubungan yang signifikan antara variabel, bukan berarti usia mengalami menarche saja yang berhubungan dengan kepercayaan diri pada remaja putri. Hubungan kedua variabel ini bersifat negatif dimana semakin cepat seorang remaja putri mengalami menarche maka kepercayaan dirinya akan semakin rendah. Dalam penelitian ini usia mengalami menarche memiliki kontribusi terhadap kepercayaan diri remaja sebanyak 18,9 \% sedangkan $81,1 \%$ lainnya merupakan sumbangan faktor-faktor lainnya seperti pengetahuan tentang menarche (menstruasi) dan kesehatan reproduksi, konsep diri remaja, pola asuh orang tua atau kedekatan dan peran ibu pada anak perempuannya dan lain-lain. Oleh sebab itu dapat disimpulkan bahwa usia mengalami menarche bukan satu-satunya faktor yang memiliki hubungan terhadap kepercayaan diri pada remaja putri di SMA N 6 Padang. 


\section{Daftar Rujukan}

[1] Al-Mighwar, Muhammad. 2006. Psikologi Remaja; Petunjuk Bagi Guru dan Orangtua. Bandung: Pustaka Setia.

[2] Ali, Muhammad dan Asrori, M. 2004. Psikologi Remaja; Perkembangan Peserta Didik. Jakarta: PT. Bumi Aksara.

[3] Azwar, Saifuddin. 2004. Penyusunan Skala Psikologi. Yogyakarta: Pustaka Pelajar.

[4] Darvill, W dan Powell, Kelsey. 2003. The Puberty Book: Panduan Untuk Remaja. Jakarta: PT. Gramedia Pustaka Utama.

[5] Davies, Philippa. Tanpa Tahun. Meningkatkan Rasa Percaya Diri. Terjemahan oleh Saut Pasaribu. 2004. Yogyakarta: Torrent Books.

[6] Goble, Frank G. 1971. Mazhab Ketiga: Psikologi Humanistik Abraham Maslow. Terjemahan oleh A. Supratiknya. 2006. Yogyakarta: Kanisius.

[7] Hasan, Iqbal. 2004. Analisis Data Penelitian Dengan Statistik. Jakarta: PT. Bumi Aksara.

[8] Hankin, Sheenah. 2004. Pede Abis: Strategi Untuk Meningkatkan Rasa Percaya Diri. Terjemahan oleh T. Hermaya. 2005. Jakarta: PT. Gramedia Pustaka Utama.

[9] Hurlock, Elizabeth B. 1980. Psikologi Perkembangan: Suatu Pendekatan Sepanjang Rentang Kehidupan. Terjemahan oleh Istiwidayanti dan Soedjarwo. 2004. Jakarta: Penerbit Erlangga.

[10] Iswidharmanjaya, D., Agung, A., dan Psycholastic. 2004. Satu Hari Menjadi Lebih Percaya Diri: Panduan Bagi Remaja yang Masih Mencari Jati Dirinya. Jakarta: PT. Elex Media Komputindo.

[11] Llewellyn, Derek dan Jones. Tanpa Tahun. Every Woman: Setiap Wanita. Terjemahan oleh Dian Paramesti Bahar. 1997. Jakarta: Delapratasa.

[12] Luxori, Yusuf. 2001. Percaya Diri. Terjemahan oleh Abdurrahman Kasdi. 2004. Jakarta: Khalifa.

[13] Malika. 2017. Hubungan Pengetahuan tentang Menstruasi dengan Kesiapan Menghadapi Menarche pada Remaja Putri di SDN Sawojajar 1 Malang. UMM Institutional Repository. Diakses tanggal 04 Desember 2019, dari http://eprints.umm.ac.id/id/eprint/40928

[14] Masland, Robert P dan Estridge, David. 2004. Apa Yang Ingin Diketahui Remaja Tentang Seks. Jakarta: Bumi Aksara.

[15] Maslow, Abraham H. 1966. Psikologi Sains; Tinjauan Kritis terhadap Psikologi Ilmuwan \& Ilmu Pengetahuan Modern. Terjemahan oleh Hani'ah. 2004. Jakarta: Teraju PT. Mizan Publika.

[16] Pramuningtyas, Woro Andani. 2007. Perbedaan Tingkat Kepercayaan Diri Pada Remaja Putri Dilihat dari Pemakaian Kosmetika Wajah. Perpustakaan Universitas Sanata Dharma Yogyakarta. Diakses tanggal 28 Oktober 2019, dari http://repository.usd.ac.id/2411/...pdf

[17] Ridha, Akram. Tanpa Tahun. Manajemen Pubertas: Panduan Ampuh Orangtua Melejitkan Kepercayaan Diri Remaja. Terjemahan oleh Akmal Burhanudin. 2006. Bandung: Syaamil Cipta Media.

[18] Sarwono, S. W. 2003. Psikologi Remaja. Jakarta: PT. Raja Grafindo Persada.

[19] Sholeha, Hidayatus. 2016. Hubungan Kesiapan Menghadapi Menarche Dengan Tingkat Kecemasan Pada Siswi Sekolah Dasar Negeri (SDN) Di Desa Ajung Kecamatan Kalisat Kabupaten Jember. Digital Repository Universitas Jember. Diakses tanggal 04 Desember 2019, dari http://repository.unej.ac.id/...handle/...pdf 
[20] Santrock, J.W. 1996. Adolescence: Perkembangan Remaja. Terjemahan oleh Shinto B. Adelar dan Sherly Saragih. 2003. Jakarta: Erlangga.

[21] Widyaningrum, Primastuti. 2010. Hubungan Antara Pengetahuan Tentang Menstruasi Dengan Sikap Menghadapi Menarche Pada Remaja Putri Di SD Negeri Bulukantil Jebres Surakarta. Perpustakaan UNS. Diakses tanggal 28 Oktober 2019, dari http://digilib.uns.ac.id/dokumen/detail/...pdf 